University of Montana

ScholarWorks at University of Montana

Graduate Student Theses, Dissertations, \&

Professional Papers

1994

\title{
Transformation of Bartonella bacilliformis by electroporation
}

Helen A. Grasseschi

The University of Montana

Follow this and additional works at: https://scholarworks.umt.edu/etd

Let us know how access to this document benefits you.

\section{Recommended Citation}

Grasseschi, Helen A., "Transformation of Bartonella bacilliformis by electroporation" (1994). Graduate Student Theses, Dissertations, \& Professional Papers. 7287.

https://scholarworks.umt.edu/etd/7287

This Thesis is brought to you for free and open access by the Graduate School at ScholarWorks at University of Montana. It has been accepted for inclusion in Graduate Student Theses, Dissertations, \& Professional Papers by an authorized administrator of ScholarWorks at University of Montana. For more information, please contact

scholarworks@mso.umt.edu. 


\section{Transformation of Bartonella bacilliformis by Electroporation}

\section{by}

\section{Helen A. Grasseschi}

B. S., The University of Montana--Missoula, 1992

Presented in partial fulfillment of the requirements for the degree of Master of Science in Microbiology The University of Montana

1994

Approved by

$\frac{X 77 \mathrm{~K}}{\text { Chairman, Board of Examiners }}$




Grasseschi, Helen A., M.S., May 1994 Microbiology

Transformation of Bartonella bacilliformis by Electroporation

Director: Michael F. Minnick M7u

Bartonella bacilliformis cannot be transformed by standard chemical methods. We report the first succesful transformation of the bacterium by the method of electroporation. The optimal conditions for electroporation of $B$. bacilliformis include a field strength of $12.5 \mathrm{kV}$ per $\mathrm{cm}$ and a time constant of $5 \mathrm{~ms}$ using $0.2 \mathrm{~cm}$ cuvettes. With these parameters and the cosmid pEST (possessing the RK2 origin of replication), a transformation efficiency of $7.8 \times 10^{5}$ CFU per $\mu$ g of DNA was obtained. Transformants were readily cultured on medium containing kanamycin sulfate at concentrations up to $600 \mu \mathrm{g}$ per $\mathrm{ml}$. Bacterial survival was approximately $30 \%$ under optimal electroporation conditions, and the maximal number of transformants was obtained with $80 \mathrm{ng}$ of PEST DNA. Verification of $B$. bacilliformis as the transformed organism was done by a comparison of transformant protein profiles to wild-type $B$. bacilliformis using sodium dodecyl sulfate-polyacrylamide gel electrophoresis (SDS-PAGE), and detection of the presence of the exogenous plasmid in DNA from the transformed bacteria by DNA hybridization. Transformations using the plasmids pMK20, pML31, and pUCK18 (containing the replicons ColE1, F, and pMB1, respectively) were unsuccessful. Attempted mutagenesis of $B$. bacilliformis using the suicide vector pRKTV14 (ColE1 replicon, Tn5 insert containing a kanamycin resistance gene) was also unsuccessful. 
All rights reserved

\section{INFORMATION TO ALL USERS}

The quality of this reproduction is dependent upon the quality of the copy submitted.

In the unlikely event that the author did not send a complete manuscript and there are missing pages, these will be noted. Also, if material had to be removed, a note will indicate the deletion.

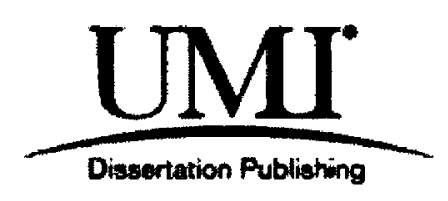

UMI EP38088

Published by ProQuest LLC (2013). Copyright in the Dissertation held by the Author. Microform Edition (C ProQuest LLC.

All rights reserved. This work is protected against unauthorized copying under Title 17, United States Code

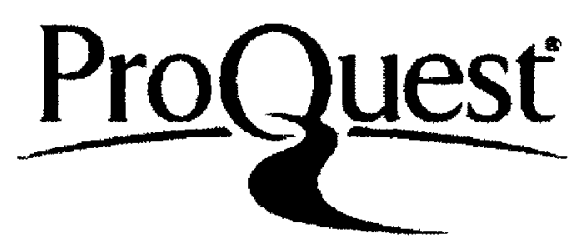

ProQuest LLC.

789 East Eisenhower Parkway

P.O. Box 1346

Ann Arbor, MI 48106 - 1346 
TABLE OF CONTENTS

ABSTRACT $\ldots \ldots \ldots \ldots \ldots \ldots \ldots \ldots \ldots \ldots \ldots \ldots \ldots \ldots \ldots \ldots \ldots$

LIST OF TABLES.......................... iv

LIST OF FIGURES ......................... iv

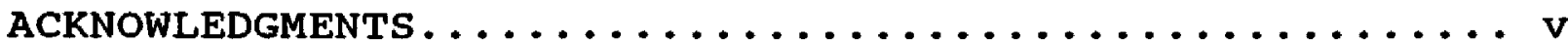

CHAPTER

I. INTRODUCTION .................... 1

1.1 Morphology and history.......... 1

1.2 Transmission and infection....... 3

1.3 Phylogenetic relationships....... 5

1.4 Transformation.............. 8



1.6 specific aims and goals........13

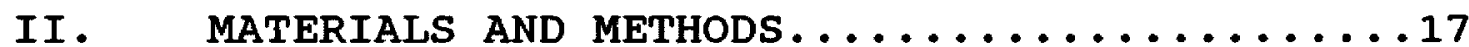

III. $\quad$ RESULTS ......................24

3.1 Optimization of

electroporation conditions......24

3.2 Effect of DNA concentration

on the number of transformants recovered and the effect of

variable field strength on the percent of cell survival........29

3.3 Verification of transformation....32

3.4 Electroporation with additional vectors, and mutagenesis.........35

IV. DISCUSSION.....................4

BIBLIOGRAPHY ............................47 


\section{LIST OF TABLES}

Table

1.1 .

Figure

1.1

1.2

3.1

3.2

$3 \cdot 3$

$3 \cdot 4$

$3 \cdot 5$

3.6
Vectors used in the attempted electroporation of $B$.

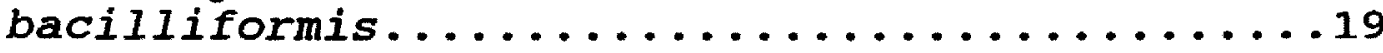

\section{LIST OF FIGURES}

Dendogram based on the sequence homology of the $16 \mathrm{~s}$

ribosomal RNA....................... 6

Diagram of pHK17, the parental plasmid



Effect of variable field strength

on the transformation efficiency of

B. bacilliformis $(200 \Omega, 5 \mathrm{~ms}) \ldots \ldots . \ldots . \ldots . . . .25$

Effect of variable field strength

on the transformation efficiency of

$B$. bacilliformis $(400 \Omega, 10 \mathrm{~ms}) \ldots \ldots . \ldots . . .27$

Effect of DNA concentration on the

number of transformants recovered..........30

Effect of variable field strength

on the post-pulse survival of

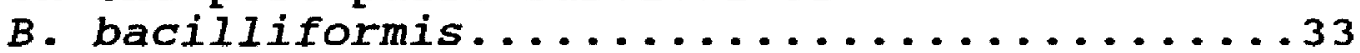

Chromosomal digest and DNA hybridization

comparing total DNA of transformed and

untransformed $B$. bacilliformis..................

SDS-PAGE protein profile comparing

whole cell lysates of transformed

and untransformed $B$. bacilliformis.........39 


\section{Acknowledgments}

I would like to express my heartfelt thanks to the members of my committee for their support and encouragement throughout my studies in the graduate program at the Uiversity of Montana. Dr. Mike Minnick has shown unending patience and optimism in his willingness to answer questions and explain protocols; without his help I would not have achieved nearly so much. He has been a good friend as well as an advisor, both in and out of the lab. I will always be glad of having had the chance to work with and know such an excellent and dedicated scientist. Dr. Tom North has taught me the art of creative thinking in science. Perhaps, with practice, I will someday be as proficient as he in that regard. He has left with me the knowledge that what is known is not always fact, and that a true scientist should always push and stretch the limits of knowledge to find the truth. Dr. Ralph Judd has been generous with his time and knowledge, and has never been too busy to offer me help or advice. I would also like to thank my parents, Mary Ann and Victor Valgenti, my in-laws Charlie and Rita Grasseschi, and most of all my husband, Rob Graseschi. We thank Dr. L.P. Mallavia for the gift of the plasmid vectors pEST, pUCK18, pML31, and pMK20. We also thank Dr. D.T. Gibson for the gift of the suicide vector pRKTV14. This work was supported by grant AI34050 from the National Institute of Health (NIAID) and by an American Cancer Society Institutional Research Grant \#290857. 


\section{CHAPTER I}

\section{Introduction}

\subsection{Morphology and history.}

Bartonella bacilliformis is an intracelluar parasite of human cells, and is the etiologic agent of oroya fever. $B$. bacilliformis is a gram negative bacterium in the eubacterial order Rickettsiales (27). The pathogen is the only known motile member of the order, and posesses a tuft of 1 to 10 unipolar flagellae. It is a small microorganism of approximately 0.25 to $0.5 \mu \mathrm{m}$ in width by 1 to $3 \mu \mathrm{m}$ in length (27), with a cell wall approximately $200 \mathrm{~nm}$ in thickness (30). B. bacilliformis is an obligate aerobe (27), and is one of the few rickettsial organisms which can be cultured on artificial media.

Bartonellosis has a very ancient history in the south American Andes, and is believed to be depicted on huacas (anthropoid ceramics) dating from about 100 A.D. to 1400 A.D. (44). Bartonellosis has been implicated in the epidemic which claimed the life of Huayana Capac, the last undisputed ruler of the Incan empire, as well as in the epidemic which later killed many of Pizarro's men (44). Due to the lack of accurate documentation and the existence of other tropical diseases which also fit the descriptions of high fever, delirium, and muscle and skeletal pains followed by an eruption of tumors (44), these 
implications cannot be proven. It is apparent, however, that bartonellosis has existed in the Andes for many years. The first documented case of the disease ocurred in 1871 when laborers were employed to build the central Railroad of Peru from the city of Lima to the city of oroya $(19,27)$. Hundreds of cases of bartonellosis occured, and the mortality rate reached approximately $40 \%$ (27).

The first demonstration that the two distinct phases of bartonellosis were produced by the same organism occured in 1885 by a Peruvian medical student, Daniel Carrion (27). Carrion entered a national scientific contest in which the best work on verruga peruana would win a prize (19). He decided to study the infectivity of verruga peruana by inoculating himself with scrapings from the lesions on an afflicted patient, and recording all signs and symptoms of the disease (19). He subsequently contracted fatal oroya fever (27). A second demonstration in 1926 by Hideyo Noguchi showed that organisms isolated from patients with either the hematic phase or the tissue phase of bartonellosis could produce oroya fever in Rhesus monkeys. $B$. bacilliformis was then re-isolated in pure culture to fulfill Koch's postulates. Unfortunately, some of these experiments have never been repeated. In fact, oroya fever has never been demonstrated in animals except in an atypical form rarely seen in experimental monkeys (42). It was, however, demonstrated in 1913 by Rocha Lima that bartonellae are definitely present within the verrugas (1). 


\subsection{Transmission and infection.}

The bacterium is transmitted through the bite of the female sandfly of the Phlebotomus genus (27). Transmission occurs at night when the female sandfly takes a blood meal, and is further restricted by the ecology of the vector (27). Bartonellosis occurs only in an area 20 north of the equator to 130 south latitude, and in a narrow region from 800 to 2600 meters above sea level (27). Humans are the only known reservoir (19).

In vitro, $B$. bacilliformis appears to enter erythrocytes through a process of forced endocytosis (27). B. bacilliformis binds to the surface of erythrocytes and induces deformation of the cell membrane, resulting in prominent pits and invaginations (3). A similar mechanism may be employed in vivo; bartonellae have been found in vacuole-like structures within erythrocytes (10). Due to the non-endocytotic nature of erythrocytes, the presence of bartonellae enclosed in vacuoles within the red blood cells (RBCs) implies a mechanism of entry initiated and mediated by the bacterium (34) . B. bacilliformis can invade capillary endothelial cells, and has been shown to be capable of invading a variety of cell types such as human dermal fibroblasts, HEp-2 cells, HeLa cells, and human umbilical vein endothelial cells (25). This ability of bartonellae to invade both HEp-2 and endothelial cells implies that the apparent preference of $B$. bacilliformis for erythrocytes may be related more to the route of entry rather than to a cell-type specificity (25). 
oroya fever (also called Carrion's disease) is endemic to the Andes regions of South America, namely Ecuador, Peru and Colombia (30). Greater than $60 \%$ of the asymptomatic population in these regions are seropositive for $B$, bacilliformis (29), and 5 to $10 \%$ of the population are active carriers of the disease (30). Bartonellosis manifests itself in two distinct phases, a primary hematic phase and a secondary tissue phase which produces localized cutaneous eruptions. The hematic phase of the disease presents with fever, malaise, diffuse bone and muscle pain, and perhaps the most severe hemolytic anemia known. $B$. bacilliformis invades nearly all erythrocytes in the blood (3), and reduces the erythrocyte population by nearly $80 \%$ (26). Within 4 to 8 weeks after recovery from the primary infection, the secondary phase presents in the form of hemangiomas, termed verruga peruana. This phase is likely due to the invasion of the capillary endothelial cells. B. bacilliformis enters the endothelial cells and replicates. The cells are then lysed by an as yet undiscovered mechanism, and the bartonellae are released and can then invade neighboring cells. The eruptions are seen on the face and extremities, and it is thought that they are caused by the hyperproliferation of the terminal vascular endothelial cells in response to an angiogenic factor released by the bacterium during infection (18). The secondary phase can also present with immunosuppression, hepatosplenomegaly, and lymphadenopathy (19). In addition, the verrugas are occasionally seen in individuals who have not displayed clinical symptons of Oroya fever. Recovery 
from bartonellosis is complete, but persistent carrier states can $\operatorname{occur}(23)$.

\subsection{Phylogenetic relationships.}

There are numerous clinically important rickettsial organisms. The order Rickettsiales encompasses a diverse group of human pathogens. In the family Bartonellaceae there are two genera and three species $(5,42)$, of which the species $B$. bacilliformis is the only human pathogen. The family Rickettsiaceae, however, contains several organisms which are infectious to humans. One example, Rickettsia rickettsii, is the etiologic agent of Rocky Mountain spotted fever and is naturally cycled through ticks and various small animals, with humans as an accidental host (27). Rochalimaea quintana is the etiologic agent of trench fever, and is transmitted in a human-louse-human cycle. It was seen in epidemic form in both World War's I and II. Coxiella burnetti and Rickettsia prowazekii, the etiologic agents of $Q$ fever and epidemic typhus, respectively, are two other members of this family.

B. bacilliformis has been found to be most closely related to $R$. quintana, Brucella abortus, and Rochalimaea henselae based on sequence homology of both the $16 \mathrm{~S}$ ribosomal RNA $(38,40)$ and the 5 S ribosomal RNA (36) (Fig. 1.1). B. abortus causes fetal abortion in cattle as well as undulant fever in humans, and 
Figure 1.1. Dendogram showing phylogenetic relationships of Bartonella bacilliformis. Family tree based on the sequence homology of the $16 \mathrm{~S}$ ribosomal RNA or 16S ribosomal RNA genes of various microorganisms from D. A. Relman, et al. (40). BA-TF stands for bacillary angiomatosis-tumor factor, which has recently been identified as the microorganism Rochalimaea henselae. 


\section{Proteobacteria}




$R$. henselae has recently been identified as the causative agent of bacillary angiomatosis (a common secondary infection in individuals infected with HIV-1) as well as cat-scratch disease. Research on the molecular biology of rickettsial pathogens is hampered by an inability to grow the majority of rickettsiae axenically, as well as an inability to perform routine genetic manipulations. Members of the order Rickettsiales have been notably difficult to transform.

\subsection{Transformation}

A good definition of natural transformation is "the process by which a bacterium absorbs pure DNA from it's surroundings and functionally integrates the exogenous DNA into it's own genetic material" (48). Natural transformation has been found to occur in many bacteria, including both Gram-positives and Gram-negatives. Transformation was initially thought to be accidental and of no particular significance, until the realization that some bacteria (e.g. Haemophilus, Neisseria) actually possess proteins that mediate the uptake of DNA as well as specifically recognizing DNA from related species (48). Organisms with this ability are called competent, and may have a distinct survival advantage over noncompetent cells. The introduction of exogenous DNA to noncompetent cells was accomplished through the infection of the bacteria by bacterial phages (i.e. transduction). However, in 1970, Mandel and Higa discovered that certain strains of 
Escherichia coli could be made artificially competent to bacteriophage $\lambda$ DNA in the absence of helper phage by the addition of $\mathrm{Ca}^{2+}$ (33). Subsequently, in 1972, Cohen, Chang, and Hsu reported the ability of $E$. coli to uptake plasmid DNA when treated with calcium chloride, and that the introduced plasmid persisted as an independently replicating unit (6). The ability to induce competence by the addition of ice-cold buffer containing $\mathrm{Ca}^{2+}$ followed by a brief heat treatment was found to be effective with many species of bacteria. This resulted in a simple method of manipulating the bacterial genome which could be used as an alternative to transduction. In transformation, plasmid vectors can be introduced into the host organism directly. In addition, transformation provides a means of introducing DNA to genetically engineer organisms and has been a major contributor to the development of recombinant DNA techniques (48).

The ability to manipulate the bacterial genome has been an important tool in understanding the various functions and mechanisms employed by the organisms. The introduction of functional DNA and the subsequent observation of the effect of that DNA on the normal activity of the bacteria, as well as the examination of the products of certain gene segments in cells which normally do not contain those segments, are methods of investigation which are revealing and relatively simple due to the tool of transformation. Since the initial experiments, many investigators have determined various ways of optimizing the 
system of transformation. Transformation efficiencies (number of transformants per $\mu$ of DNA) can be increased through longer incubations with calcium chloride (11), the addition of several different cations to the reaction mixture (37), and the treatment of the bacteria with dimethyl sulfoxide (DMSO), hexaminecobalt, and dithiothreitol in the presence of monovalent and divalent cations (21). Manipulations of these protocols have extended the list of microorganisms which have been succesfully and stably transformed. Unfortunately for rickettsiologists, these methods have proved incapable of rendering rickettsial organisms competent. To date, Rochalimaea quintana is the only member of the Rickettsiales order to be stably transformed (41).

\subsection{Electroporation.}

R. quintana was stably transformed with the cosmid vector pEST by the method of electroporation (41). Electroporation is a physical, rather than a chemical, method of transformation. It involves the introduction of an electric current to a solution containing both bacterial cells and exogenous DNA (15). This procedure was first developed for use in the introduction of exogenous DNA into both plant protoplasts (17) and mammalian cells (7), and has been shown to increase the frequency of eukaryotic cell fusion events (51). At this point, several investigators developed electroporation systems for use with bacterial cells. In general, bacterial electroporation involves 
small-volume samples of high resistance, high voltages, and narrow electrode gaps. Intact bacteria of many species have been succesfully transformed by electroporation, but the actual mechanism of exogenous DNA uptake has not been elucidated.

In prokaryotic electroporation, an electric pulse of high voltage is applied to a DNA-plus-bacteria cell suspension for a period of time using a suitable capacitor, e.g. the Bio-Rad Gene Pulser. The electric field is defined as the voltage applied across the distance between electrodes:

$$
\mathbf{E}=\mathrm{V} / \mathbf{d}
$$

Both the electric field and the voltage applied quickly rise to a peak ( $E_{0}$ and $V_{0}$, respectively) and then decline over time,

$$
\begin{aligned}
E_{(t)} & =E_{0}\left[e^{-(V \tau)}\right] \\
V_{(t)} & =V_{0}\left[e^{-(v \tau)}\right]
\end{aligned}
$$

where $\tau$ is the RC time constant (resistance [ohms] times capacitance [farads]) and is recorded in seconds or milliseconds (ms). Using a Bio-Rad Pulse controller unit, the sample is placed in series with a $20 \mathrm{ohm}(\Omega)$ resistor and in parallel with a selection of 100 to $1000 \Omega$ resistors (15). The total resistance of the system is then

$$
1 / R_{\text {total }}=1 / R_{\text {series }}+R_{\text {sample }}+1 / R_{\text {parallel.1 }}+1 / R_{\mathrm{p} .2} \ldots+1 / R_{\mathrm{p} . x}
$$

where $x$ equals the total number of resistors set in parallel to the sample. If the resistance of the sample is high, then the resistance of the system is determined by the resistors in parallel to the sample. As a result, the duration of the pulse (RC time constant) can be determined manually, and held constant. 
The $20 \Omega$ resistor is used to limit the current and protect the instrument should arcing of the sample occur (15).

The mechanism of electroporation appears to rely on a reversible permeabilization of the cellular membrane. Tsong (47) suggested several properties of cellular membranes which could lend themselves to permeabilization by electrical currents. First, the charges on the lipid molecules would cause them to reorient in an intensely applied electric field, resulting in hydrophilic pores and an inability to function as a barrier against ions. Also, the finite permeability of the membrane to small ions would conduct current and generate local Joule heating, which would result in thermal phase transitions of the bilayer. Both of these events would result in lipid bilayer rearrangement; the expansion or creation of hydrophobic pores and the formation of structurally stable hydrophilic pores. Another possibility is that electroporation in a cell membrane can also occur in protein channels, which are also known to depend on transmembrane electric potential $(22,46)$.

There is a compensatory relationship between the amplitude of the electric field and the duration of the pulse (15, 47). As the electric field is increased, the time constant must be decreased in order to maintain optimal transformation efficiencies. The opposite of this is also true; as the time constant is increased the amplitude of the electric field must be decreased. This relationship is due to the reversible nature of the conformational changes induced in the cell membrane. If the 
electric field is high, the amount of rearrangement and molecular inversion will be high. In order to avoid irreversible damage to the cell membrane, the duration of the pulse must be short enough to allow the cell membrane to 'reseal' itself in a functional manner. If the electric field applied is of low magnitude, the cell will be able to tolerate the applied current for a longer period of time without undergoing irreversible damage.

The actual uptake of DNA into the host cell appears to be accomplished by either passive diffusion of the DNA into the cell or bulk flow of the medium containing the DNA into the cell (15). The observation that a pre-electroporation incubation does not significantly change efficiencies of transformation implies that there is no need for the DNA to bind to the cells prior to transformation. Whatever the actual mechanism, electroporation appears to depend upon a physical property of bacterial cells (i.e. the presence of a cellular membrane) $(7,37)$ and this may account for the high rate of success seen with many different organisms as well as cell types.

\section{6 specific aims and goals.}

Given the close phylogenetic relationship between Rochalimaea species and $B$. bacilliformis (Fig. 1) $(36,38)$, as well as the ability to grow bartonellae axenically, we wanted to 
determine if $B$. bacilliformis could be stably transformed using the method of electroporation. Several attempts to transform $B$. bacilliformis using classical chemical methods had previously failed in our hands.

In the transformation of $R$. quintana by electroporation (41), several vectors, were used. We concerned ourselves only with those which contained a gene for kanamycin resistance. These vectors were pEST (41, Fig. 1.2), pUCK18, pMK20, and pML31 (41, 28, and 32 respectively, described in Table 1.1).

In this study we optimized the conditions for stable transformation of $B$. bacilliformis by electroporation using the cosmid vector pEST (41). We then attempted transformation of $B$. bacilliformis with several other vectors possessing different origins of replication to determine which replicons are functional in $B$. bacilliformis. Expression of the exogenous DNA by the bacterium was demonstrated by stable growth on selective media containing kanamycin sulfate, and transformation was verified by both DNA hybridization and SDS-PAGE analysis of cell lysates from the transformed organisms. 
Figure 1.2. Diagram of the cosmid pHR17; the parent of the cosmid vector pEST (41). The tetracycline resistance gene was excised from the cosmid pHK17, and the resulting cosmid was called pEST (41). Abbreviations: tet ${ }^{r}$, tetracycline resistance; kan ${ }^{r}$, kanamycin resistance; cos represents a $\lambda$ cos site present on the vector. The RK2 ori is the RK2 origin of replication. 

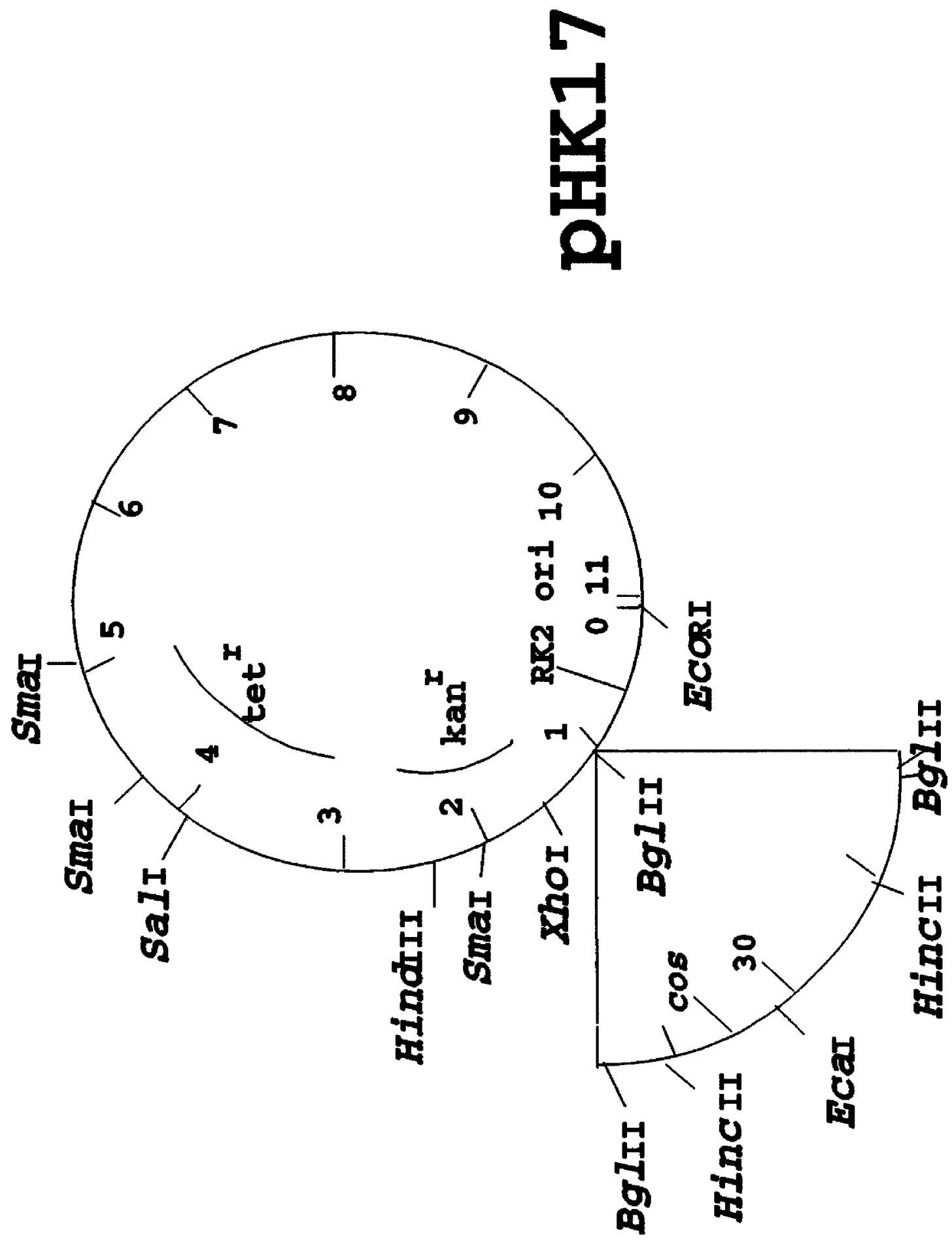
CHAPTER II

\section{Materials and Methods}

Bacterial growth conditions. B. bacilliformis, strains KC583 and KC584 were purchased from the American Type culture Collection, Rockville, Md. The bacteria were grown in high humidity at $300 \mathrm{C}$ on HIBB [heart infusion agar, (Difco Laboratories) enriched with 5\% defibrinated sheep erythrocytes $(v / v)$ and $5 \%$ filter-sterilized sheep serum $(v / v)$ (Colorado serum Co.)]. Bartonellae were typically harvested at 4 days postinoculation. Escherichia coli strains containing the plasmids of interest (Table 1.1) were routinely grown overnight in LuriaBertani medium (12) at $370 \mathrm{C}$ with constant shaking. When required, kanamycin sulfate (Sigma Chemical Co.) was added to the growth medium at concentrations ranging from 15 to $600 \mu \mathrm{g}$ per $\mathrm{ml}$. DNA isolation. Plasmids used in this study are listed in Table 1.1, and were extracted and purified from $E$. coli using standard alkaline extraction (4), or by a Quiagen Midi Prep kit 
(Quiagen, Inc.). For the alkaline extraction, the cells were lysed with lysozyme, $0.01 \mathrm{M}$ EDTA, and $0.25 \mathrm{M}$ Tris (pH 8.0). The proteins were denatured by the addition of $400 \mu 110 \%$ (w/v) sodium dodecyl sulfate (SDS), and the total DNA was precipitated with $300 \mu 13 \mathrm{M}$ sodium acetate (pH 5.0). The plasmids were then shaken out of the protein/DNA clot. After centrifugation, the supernatant was aspirated and the plasmid DNA was precipitated with isopropanol, resuspended in $0.052 \mathrm{M}$ Tris (pH 8.0) plus 0.102 M sodium acetate, and precipitated again with $95 \%$ ethanol. Isolated plasmids were further purified by a chloroform: isoamyl alcohol $(24: 1 ; \mathrm{v} / \mathrm{v})$ extraction followed by a $95 \%$ ethanol precipitation. Plasmid concentrations were obtained visually by comparing to DNA standards of known concentration on ethidium bromide-stained agarose gels and/or by optical density readings at $260 \mathrm{~nm}$. The cosmid pEST was used to optimize the transformation of $B$. bacilliformis by virtue of its successful use in $R$. quintana (41) and is diagrammed in Fig. 1.2.

The chromosomal DNA of both transformed and untransformed $B$. bacilliformis was extracted by standard protocol (2) . Briefly, bacteria were harvested at 4 days post-inoculation into $100 \mu \mathrm{TE}$ buffer (10 mM Tris-HCl, $1 \mathrm{mM}$ sodium EDTA, pH 7.4), containing 5 $\mu 1$ of $10 \% \operatorname{SDS}(\mathrm{w} / \mathrm{V})$ and $40 \mu \mathrm{g}$ of proteinase $\mathrm{K}$ (Sigma). The mixture was incubated for $1 \mathrm{~h}$ at $500 \mathrm{C}$. The DNA was subsequently extracted with 1 volume of phenol:chloroform: isoamyl alcohol $(25: 24: 1 ; \mathrm{v} / \mathrm{v} / \mathrm{v})$, gently shaken, and centrifuged for $1 \mathrm{~min}$ at $16,000 \times \mathrm{g}$ in a microcentrifuge. The aqueous phase was 
TABLE 1. List of cosmids and plasmids with kanamycin-resistance genes used to transform $B$. bacilliformis by the method of electroporation

Vector

pUCK18

PMK20

PML31

pEST

PRKTV14

asuccesful transformation

was verified

by
Succesful transformation was determined by a minimum of six

\section{Reference ${ }^{b}$}

41

28

32

41

52 experiments.

boriginal description of vector. 
aspirated and extracted with 1 volume of chloroform-isoamyl alcohol $(24: 1 ; \mathrm{v} / \mathrm{v})$ and was vortexed and centrifuged again. The aqueous phase was collected, and $15 \mu 1$ of $2 \mathrm{M}$ ammonium acetate ( $\mathrm{pH} 7.0$ ) was added and mixed. The DNA was precipitated by adding $1 \mathrm{ml}$ of $95 \%$ ethanol and incubating for $20 \mathrm{~min}$ at $220 \mathrm{C}$. The precipitate was then centrifuged for $15 \mathrm{~min}$ at $16,000 \times 9$. The resulting DNA pellet was dried and resuspended in $50 \mu 1$ sterile distilled water and frozen at $-200 \mathrm{C}$ until needed.

southern blotting. Chromosomal or plasmid DNA was digested to completion with SmaI (GIBCO-BRL), and the resulting digest was run on an ethidium bromide-stained-0.8\% agarose (w\v) gel at $15 \mathrm{~V}$ overnight. Blotting of the gel to nitrocellulose $(0.45 \mu \mathrm{m}$ pore size) (Schleicher and Schuell, Inc.) was accomplished by the methods of Southern (45). The gel was washed in $0.25 \mathrm{~N} \mathrm{HCl}$ for depurination for $15 \mathrm{~min}$. It was then incubated in the southern base solution ( $0.5 \mathrm{~N} \mathrm{NaOH,} 1.5 \mathrm{M} \mathrm{NaCl)}$ for $15 \mathrm{~min}$, rinsed briefly in distilled water, and washed in the southern base for an additional $30 \mathrm{~min}$. The gel was neutralized to a pH of 8.0 to 8.5 in southern neutralization buffer $10.5 \mathrm{M} \operatorname{Tris}-\mathrm{HCl}, 3.0 \mathrm{M} \mathrm{NaCl,} \mathrm{pH}$ 7.0), and rinsed briefly with $2 x$ ssc ( $90 \mathrm{mM}$-sodium chloride plus $9.0 \mathrm{~mm}$-sodium citrate) to remove the neutralizing buffer. The gel was placed on whatman filter paper on a wick blotter.

Nitrocellulose paper (NCP) was cut to the size of the gel, wetted and equilibrated with $20 x$ SSC, and placed onto the gel surface, followed by whatman paper and paper towels. The nitrocellulose filter paper (NCP) was weighted to aid in the wicking process, 
and after 12 to $16 \mathrm{~h}$ was dried, baked at $800 \mathrm{C}$ for $60 \mathrm{~min}$, and placed in a pre-hybe solution (6x SSC plus 10x Denhardt's reagent [43]) for $1 \mathrm{~h}$. This was followed by a $4 \mathrm{~h}$ equilibration in the hybridization solution (5X SSC, 5X Denhardt's, $20 \mathrm{mM} \mathrm{Tris}-\mathrm{HCl}[\mathrm{pH}$ 8.0], 1.0 mM EDTA, $0.1 \%$ sodium dodecyl sulfate [SDS], and 20 $\mu \mathrm{g} / \mathrm{ml}$ salmon sperm DNA). The NCP was then hybridized overnight at $450 \mathrm{C}$ with SmaI-digested pEST cosmid (41) which had been radiolabeled with $\left[\alpha{ }^{32} \mathrm{P}\right] \mathrm{dCTP}$ by random primer extension (16). For radiolabeling, the pEST cosmid probe was digested to completion with SmaI, and heat denatured for $10 \mathrm{~min}$. The digested, denatured DNA was immediately placed on ice to prevent reannealing. OLB buffer (0.10 mM dATP, $0.10 \mathrm{mM}$ dGTP, $0.10 \mathrm{mM}$ dTTP, random hexamers [27 OD units/ml], and buffer $[0.24 \mathrm{M} \operatorname{Tris-HCl,~1.0~M~Hepes,~} \mathrm{pH}$ 6.6]), bovine serum albumin (BSA, 20 $\mu \mathrm{g}), 50 \mu \mathrm{Ci}\left[\alpha-{ }^{32} \mathrm{P}\right] \mathrm{dCTP}$ (NEN), and 2 units of $E$. coli DNA polymerase I klenow fragment (GIBCOBRL) were all added, and the reaction $\mathrm{mix}$ was incubated at room temperature for $4 \mathrm{~h}$. After incubation, the probe was heat denatured and added to the hybridization mixture. After hybridization, the blot was washed four times at high stringency for $30 \mathrm{~min}$ at $650 \mathrm{C}$ with $1 \times \mathrm{SSC}$ with $0.1 \% \mathrm{SDS}$ (w/v) and $5 \mathrm{mM-EDTA}$ added. The blot was then exposed onto XAR-5 X-OMAT (Kodak Co.) film to visualize the hybridized DNA bands.

8Ds-polyacrylamide gel electrophoresis. Transformed or wild type strains (KC583 and KC584) of $\mathrm{B}$. bacilliformis were harvested from HIBB, pelletted by centrifugation at $2940 \times \mathrm{g}$ for $5 \mathrm{~min}$, and resuspended in $75 \mu l$ ice-cold, sterile distilled water. An equal 
volume of Laemmii sample buffer (31) was added, and the mixture was boiled for $5 \mathrm{~min}$ to denature the proteins. Denatured proteins were then electrophoresed on SDS-PAGE (12.5\% acrylamide; w/v) gel by the general methods of Laemmli (31). The gel was subsequently fixed for $30 \mathrm{~min}$ in $50 \%$ methanol $(\mathrm{v} / \mathrm{v})$ and silver stained by the methods of wray et al. (49).

Electroporation of $B$. bacilliformis. Bartonellae were aseptically harvested from HIBB plates into $1 \mathrm{ml}$ of heart infusion broth (Difco) at 220C. The suspension was centrifuged at $2940 \times 9$ for $5 \mathrm{~min}$ at $40 \mathrm{C}$. The pellet was then washed with $1 \mathrm{ml}$ of ice-cold $10 \%$ glycerol-water $(v / v)$, and centrifuged again for 5 min at $2940 \times \mathrm{g}$. The bacterial cell concentration was obtained using a Petroff-Hauser counter and adjusted to $1 \times 10^{10} \mathrm{cells} / \mathrm{ml}$ with $10 \%$ glycerol. Forty $\mu l$ of the bacterial suspension $\left(4 \times 10^{8}\right.$ cells) was then mixed with 20 ng of plasmid DNA in a microcentrifuge tube, transferred to a $0.2 \mathrm{~cm}$ gap electroporation cuvette (Bio-Rad Laboratories), and chilled on ice for $5 \mathrm{~min}$. Electroporation was then performed using a Bio-Rad Gene Pulser (model \#1652076) with an exponential decay waveform set at field strengths of $12.5,10,8$, and $6 \mathrm{kv} / \mathrm{cm}$, and at pulse times of 5 and $10 \mathrm{~ms}$, (i.e. resistance values of 200 and $400 \Omega$, respectively). The capacitance was held constant at 25 uF for all experiments.

Immediately following electroporation, bacteria were rinsed with $1 \mathrm{ml}$ of sterile recovery broth [heart infusion broth containing $0.5 \%(\mathrm{w} / \mathrm{v})$ bovine serum albumin, and $5 \%(\mathrm{v} / \mathrm{v})$ human 
erythrocyte lysate (3) prepared by mixing 1 volume of outdated human red blood cells (American Red cross) with 3 volumes of cold distilled water, gently shaking to lyse, and centrifuging at 3000 $x \mathrm{~g}$ for $15 \mathrm{~min}$ at $40 \mathrm{C}$ to remove debris] and incubated at $300 \mathrm{C}$ for $14 \mathrm{~h}, \mathrm{i} . e$. approximately two bartonellae generation times (3). Following incubation, the electroporated bacteria were plated onto HIBB plates containing kanamycin sulfate at $15 \mu \mathrm{g}$ per ml. Suspected transformants were subcultured at 6 days postinoculation onto HIBB-kanamycin plates for use in SDS-PAGE and/or DNA isolation. Colony forming units (CFU) were counted to determine transformation efficiencies and the percent of bacterial cell survival, as well as to determine the effect of plasmid DNA concentration on the transformation efficiency.

statistical analysis. Numerical values in this study are expressed as the mean \pm standard error of the mean (SEM), with the number of trials equal to $3(n=3)$. Statistical significance of the data was determined through the use of students $t$ test, were a $P$ value $<0.05$ was considered significant. 


\section{CHAPTER III}

Results

\subsection{Optimization of electroporation conditions.}

Initial transformants were obtained by applying a field strength of $12.5 \mathrm{kV}$ per cm to the bacterial cell-pEST DNA suspension for $10 \mathrm{~ms}$. Colonies began to appear at approximately 6 days following electroporation and were typically smaller than colonies formed by untransformed $B$. bacilliformis at the same time after inoculation. There was an apparent growth lag time of approximately 2 days as compared to untransformed bartonellae. Growth was observed on HIBB plates containing kanamycin sulfate at concentrations ranging from $15 \mu \mathrm{g}$ per ml (usual selection pressure) to $600 \mu \mathrm{g}$ per $\mathrm{ml}$. The transformants could be subcultured repeatedly on the selective medium, suggesting that stable transformation had ocurred. Upon subculturing, the growth of the transformants resembles that of the wild-type bartonellae (i.e. colony size, rate of growth).

To determine which voltages produced optimal transformation efficiencies, B. bacilliformis was transformed with the cosmid vector pEST at field strengths of $12.5,10,8$, and $6 \mathrm{kV}$ per $\mathrm{cm}$ and at time constants of 5 (Fig. 3.1) and 10 (Fig. 3.2) ms. At both time constants, the optimal transformation efficiency occurred when an electric field of $12.5 \mathrm{kV}$ per $\mathrm{cm}$ was applied to 
Figure 3.1. The effect of field strength on the transformation efficiency of $B$. bacilliformis. $B$, bacilliformis was electroporated with $25 \mathrm{ng}$ of PEST DNA at a resistance of $200 \Omega$ and a capacitance of $25 \mu \mathrm{F}$, which translates to a time constant of $5 \mathrm{~ms}$. Each data point represents the average of three experiments +/- SEM. Transformation efficiency is recorded as CFU $\times 10^{5}$ per $\mu \mathrm{g}$ of PEST DNA. 


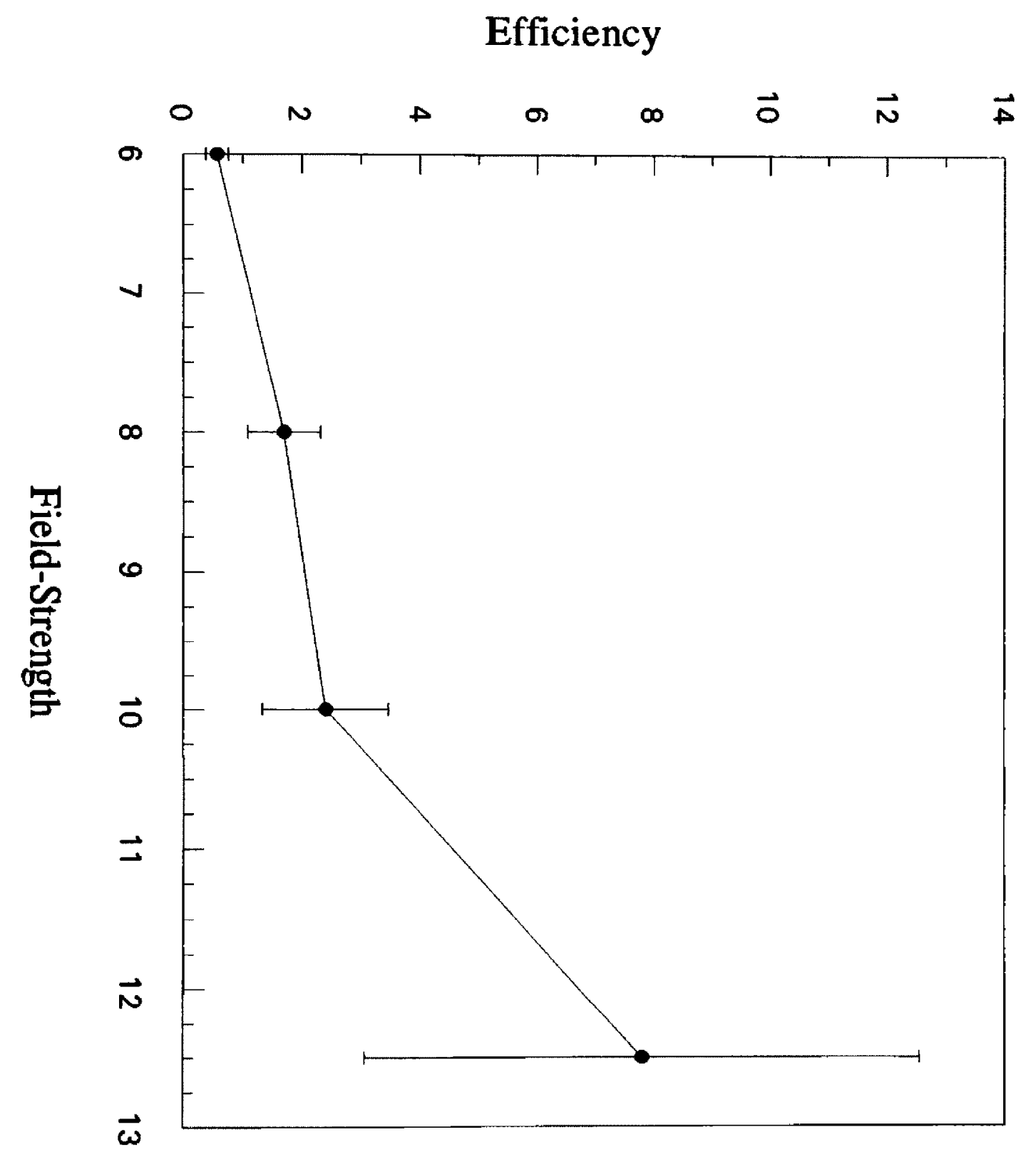


Figure 3.2. The effect of field strength on the transformation efficiency of $B$. bacilliformis. B. bacilliformis was electroporated with $25 \mathrm{ng}$ of pEST DNA at a resistance of $400 \Omega$ and a capacitance of $25 \mu \mathrm{F}$, which translates to a time constant of $10 \mathrm{~ms}$. Each data point represents the average of three experiments +/- SEM. Transformation efficiency is recorded as CFU $x 10^{5}$ per $\mu g$ of pEST DNA. 





transformation mixture. Although not statistically significant, the transformation efficiencies obtained at $5 \mathrm{~ms}$ (Fig. 3.1) were slightly higher than the efficiencies obtained at $10 \mathrm{~ms}$ (Fig. 3.2). As a result, all subsequent experiments were performed using a time constant of $5 \mathrm{~ms}$.

The transformation efficiencies showed a direct correlation with the field strength applied during electroporation (Fig. 3.1) optimal transformation efficiencies of $7.8 \times 10^{5}$ were obtained at a voltage of $2.5 \mathrm{kV}$, which corresponds to a field strength of $12.5 \mathrm{kV}$ per $\mathrm{cm}$. These results are similar to those obtained for the closely-related bacterium, $R$. quintana (41). However, due to the limits of the Bio-Rad Gene Pulser and the $0.2 \mathrm{~cm}$ electroporation cuvettes, field strengths beyond $12.5 \mathrm{kV}$ per $\mathrm{cm}$ could not be analyzed. It is possible that greater field strengths may yield greater transformation efficiencies since an apparent peak value was not obtained (Fig. 3.1 and Fig 3.2).

\subsection{The effect of DNA concentration on the number of} transformants recovered and the effect of variable field strength on the percent of bacterial cell survival.

The effect of DNA concentration on the transformation efficiency under optimal conditions was also analyzed using Quiagen-purified pEST cosmid (Fig. 3.3). Serial dilutions of the PEST DNA were carried out, and $B$. bacilliformis was electroporated under optimal conditions (i.e. $12.5 \mathrm{kV}$ per cm, 5 
Figure 3.3. The effect of pEST cosmid DNA concentration on the transformation of $B$. bacilliformis. Electroporation conditions were optimal, i.e. $12.5 \mathrm{kV}$ per $\mathrm{cm}, 5 \mathrm{~ms}$, and $25 \mu \mathrm{F}$. Each data point represents the mean of three experiments $+/-$ SEM. 


\section{Transformants}

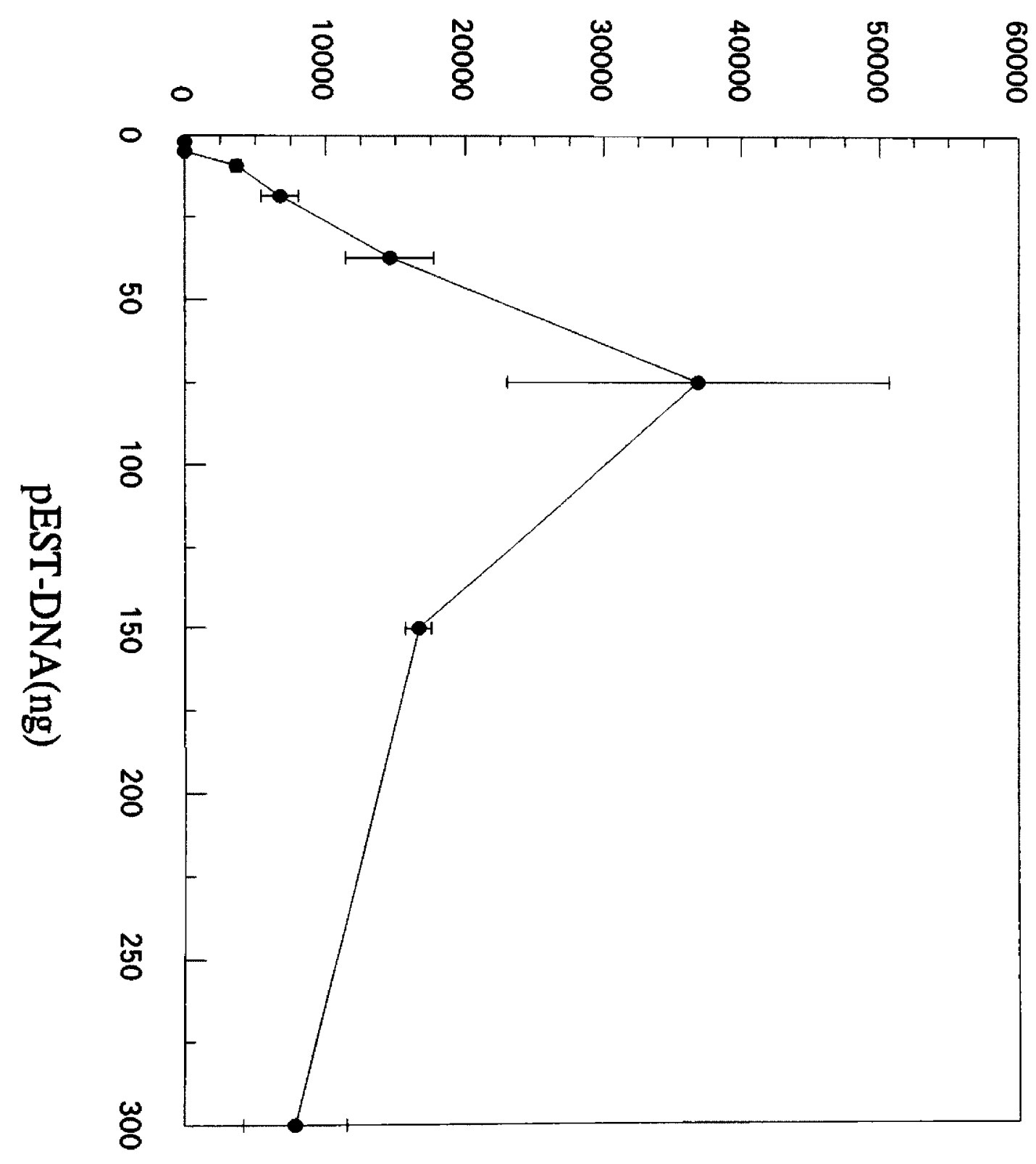


ms) with DNA concentrations ranging from 2 to $300 \mathrm{ng}$. The greatest number of transformants (determined by counting colony forming units [CFU]) was observed when the bacteria were electroporated with $80 \mathrm{ng}$ of pEST DNA (Fig. 3.3).

Bacterial cell survival during electroporation was also determined (Fig. 3.4). B. bacilliformis was electroporated in the absence of exogenous DNA at $12.5,10,8$, and $6 \mathrm{kV}$ per cm. The percentage of cells surviving electroporation (i.e. CFU on the growth media) as a function of field strength was then calculated using un-treated bartonellae as a negative control. The percent survival for B. bacilliformis at optimal conditions was approximately 30\% (Fig. 3.4). This value compares favorably to the percent survival at optimal electroporation conditions for $R$. quintana, where survival values of approximately $20 \%$ were obtained (41).

\subsection{Verification of transformation.}

Southern blot analysis was performed on the extracted chromosomal DNA of transformed bacteria to verify the presence of the pEST cosmid. DNA hybridization was performed as described above. The radiolabeled pEST hybridized to comigrating bands of 16,000 and 6,000 base pairs $(\mathrm{bp})$ in both the smaI-digested pEST cosmid and in the smaI-digested DNA obtained from transformed $B$. bacilliformis (Fig. 3.5B, lanes 4 and 3 , respectively). The hybridization data demonstrates that the fragments contained 
Figure 3.4. The effect of field strength on the post-pulse survival of electroporated B. bacilliformis. Bacteria were electroporated at $5 \mathrm{~ms}$ and $25 \mu \mathrm{F}$. Each data point represents the mean percent survival of three experiments +/- SEM. 


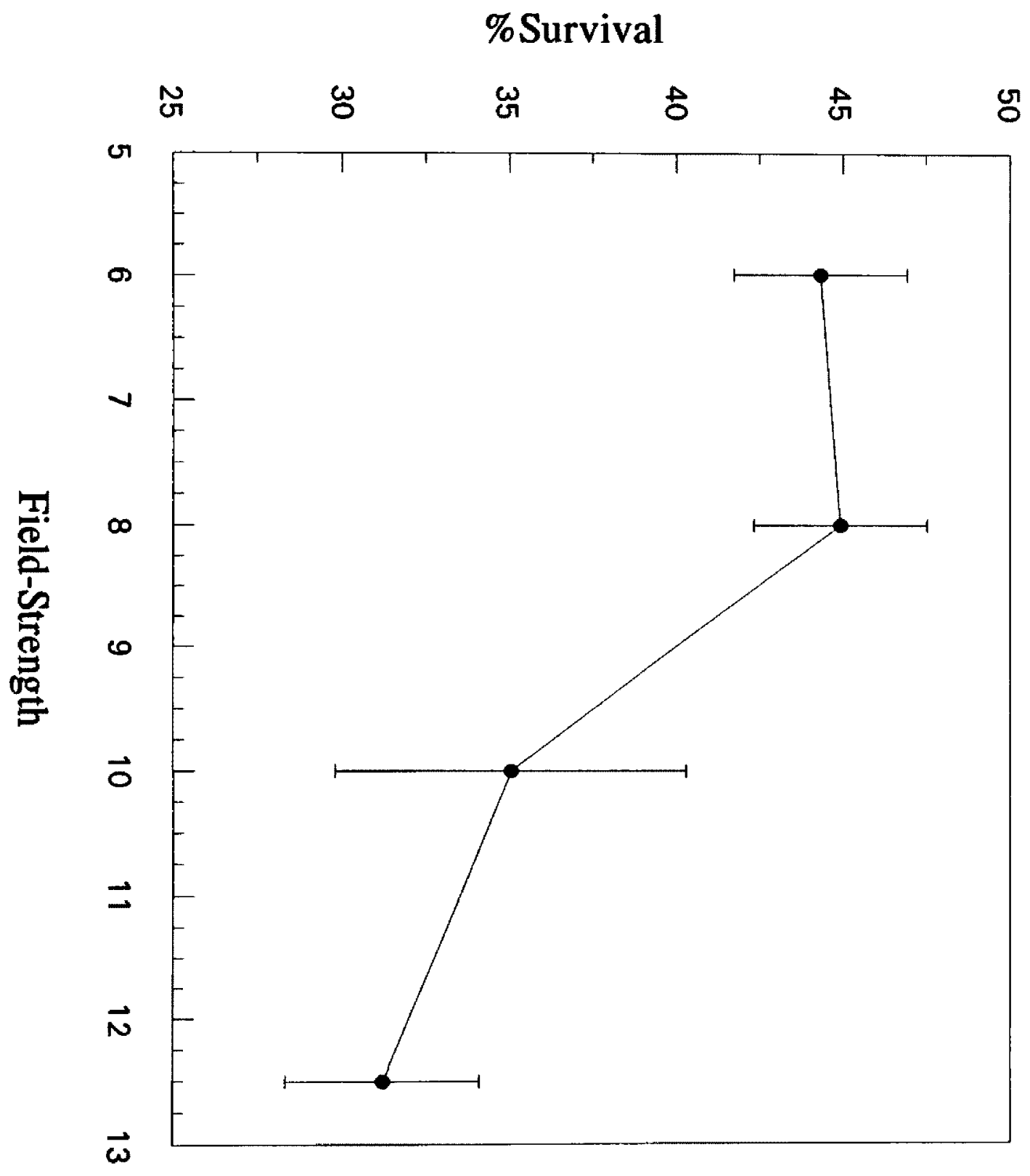


within the transformed $B$. bacilliformis total DNA are fragments of the PEST cosmid and that no hybridization occurs on the chromosomal DNA of untransformed bartonellae (Fig. 3.5B, lane 2). The slight hybridization signal in the $\lambda$ HindIII size standard (Fig. 3.5B, lane 1) is presumably due to homologous regions common to both the pEST cosmid and the $\lambda$ marker (i.e. $\lambda$ cos sites). Comparison of the DNA-fragment banding patterns for both the native and transformed strains of $B$. bacilliformis (Fig. 3.5A) demonstrates comigration of all bands except for the 16,000 and $6,000 \mathrm{bp}$ fragments seen in the chromosomal digest of the transformed strain. This suggests that the transformed bacteria is $B$. bacilliformis.

Further verification of the transformed bacteria as $B$. bacilliformis was determined by SDS-PAGE protein profiles of the cell lysate (Fig. 3.6). SDS-PAGE protein profiles of cell lysates comparing transformed $B$. bacilliformis to untransformed $B$. bacilliformis were electrophoresed and subsequently silver stained. The resulting protein profile seen in this gel (Fig. 3.6) was identical for both strains of native $B$. bacilliformis (KC583 and KC584) as well as the transformed bartonellae. These data again demonstrate that the transformed organism was $B$. bacilliformis.

\subsection{Electroporation with additional vectors and mutagenesis.}

Transformation by electroporation of $B$. bacilliformis was 
Figure 3.5. Chromosomal digest and DNA hybridization analysis comparing total DNA of untransformed $B$. bacilliformis and $B$. bacilliformis transformed with pEsT. (A) Ethidium bromide-stained agarose gel $(0.8 \%, w / v)$. Lane $1, \lambda H$ ind III size standard (indicated to the left in $\mathrm{kb}$ ); lane 2, SmaI-digested total DNA from native $B$. bacilliformis (KC584); lane 3, SmaI-digested total DNA from transformed B. bacilliformis (KC584); lane 4, SmaIdigested pEST cosmid (39) DNA. (B) Corresponding DNA hybridization of gel pictured in (A) blotted and susequently probed with ${ }^{32} \mathrm{P}-1$ abeled pEST DNA. Co-migrating hybridization signals (lanes 3 and 4 ) are arrowed. 




B

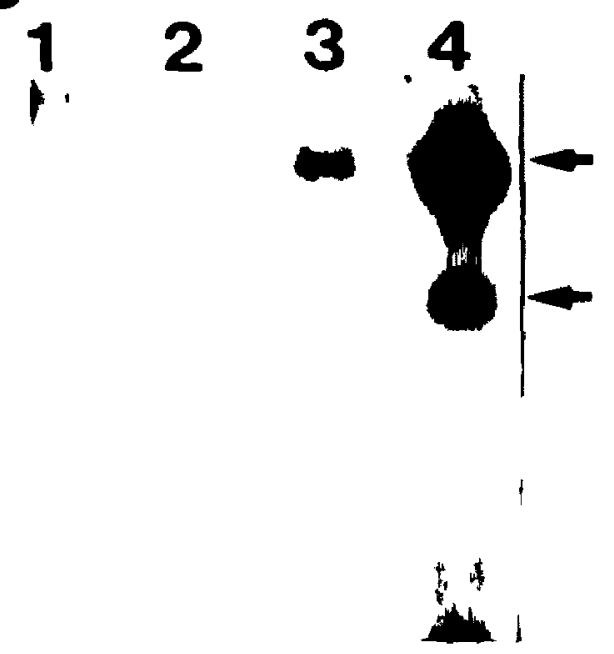


attempted using the vectors pUCK18, pML31, and pMK20 possessing the origins of replication pMB1, F, and colEl, respectively (Table 1.1). Electroporations were performed at optimal conditions for transformation with pEST. At approximately 8 days post-electroporation possible transformants were observed. However, upon prolonged incubation (i.e. 14 days) and attempts at subculturing, the transformation was seen to be unstable. No stable transformants were recovered through the course of 6 trials, and southern blot analysis showed no $B$. bacilliformis in the samples collected at 8 days post-electroporation. These results were consistent with those for $R$. quintana using the same replicons (41).

Mutagenesis of $B$. bacilliformis was attempted using the suicide vector pRKTV14 (52). This vector possesses the colEl replicon as well as a Tn5 insert which contains a gene for kanamycin resistance. Upon introduction into the host cell, the vector undergoes several rounds of replication before failing. This would allow the transposase gene of Tn5 to be transcribed, and the transposon could then randomly insert itself into the host chromosome. Electroporation of $B$. bacilliformis was performed at optimal conditions with the suicide vector pRKTV14. The results were as described for transformation by vectors other than the pEST cosmid. Possible transformants were observed at 8 days post-inoculation, but were not stable under prolonged incubation ( 14 days) or attempted subculturing. 
Figure 3.6. SDS-PAGE (12.5\% acrylamide, w/v) protein profile comparing the banding patterns of cell lysates of native $B$. bacilliformis and $B$. bacilliformis transformed with the pEST cosmid. Lane 1, protein molecular mass standards; lane 2, pESTtransformed $b$. bacilliformis (KC584); lane 3, B. bacilliformis (KC583); lane 4, B. bacilliformis (KC584). $M_{r}$ values for the protein standards are given to the left in kDa. 


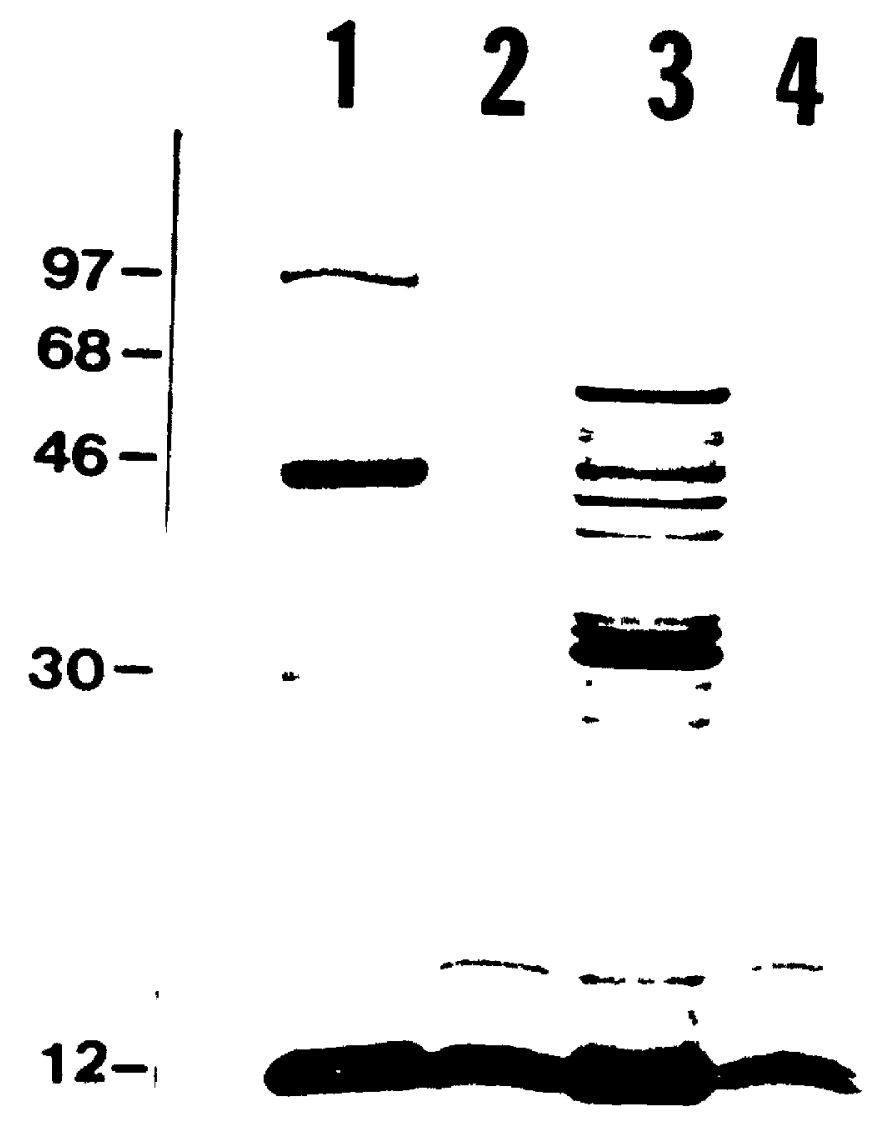




\section{CHAPTER IV}

\section{Discussion}

This study describes the first successful transformation of a member of the Bartonellaceae family, and only the second member of the Rickettsiales order. Using the pEST vector (41) and parameters which had been used with success for the closelyrelated bacterium $R$. quintana (41), we developed and optimized a system for the stable transformation of $B$. bacilliformis, obtaining transformation efficiencies up to $7.8 \times 10^{5} \mathrm{CFU} / \mu \mathrm{g}$ DNA. A further study involving either increased voltages or decreased cuvette gaps would allow the investigator to determine if electric fields greater than $12.5 \mathrm{kV}$ per $\mathrm{cm}$ (the maximal amplitude used in this study) would result in increased transformation efficiencies. Dower et al. electroporated $E$. coli using electroporation cuvettes with a gap distance of $0.15 \mathrm{~cm}$ (15). At $2.5 \mathrm{kV}$, this translates to a field strength of $16.7 \mathrm{kV}$ per cm. Transformation efficiencies for $E$. coli, when subjected to a field strength of this magnitude, were decreased as compared 
to the efficiencies obtained at $12.5 \mathrm{kV}$ per $\mathrm{cm}$. Both $B$. bacilliformis and $R$. quintana displayed optimal transformation efficiencies at $12.5 \mathrm{kV}$ per $\mathrm{cm}$, with no apparent peak value. In light of the data obtained for $E$. coli and the ease with which $E$. coli is transformed as compared to the rickettsial organisms, it is possible that if $B$. bacilliformis were exposed to higher field strengths the transformation efficiencies would decline. The efficiencies obtained in this study, however, are adequate for further research requirements, and subculturing provides vigorous growth of the transformants. The transformants are viable after freezing at $-700 \mathrm{C}$ in $12.5 \%(\mathrm{v} / \mathrm{v})$ glycerol, and regain vigorous growth after a 2 to 3 -day lag period. The transformed bacteria were able to grow on HIBB plates containing kanamycin sulfate at concentrations ranging from $15 \mu \mathrm{g}$ per $\mathrm{ml}$ up to $600 \mu \mathrm{g}$ per $\mathrm{ml}$. Both newly transformed bartonellae and specimens frozen at $-700 \mathrm{C}$ displayed stable growth when subcultured on media containing the antibiotic at $600 \mu \mathrm{g}$ per $\mathrm{ml}$.

The effect of exogenous DNA concentration on the transformation efficiency of $B$. bacilliformis was consistent with the literature for other organisms. The transformant recovery of $B$. bacilliformis increased linearly with increasing DNA concentrations up to $80 \mathrm{ng}$ (Fig. 3.3). For E. coli, transformant recovery increased linearly with DNA concentrations over a range from $0.4 \mathrm{pg}$ to $0.3 \mu \mathrm{g}$ of added DNA, with no peak value reached (15). The same was true for Acidiphilium strains up to a DNA concentration of $10 \mu \mathrm{g} / \mathrm{ml}(20)$. 
Our data displayed a peak number of bartonellae transformants at $80 \mathrm{ng}$, with a subsequent decrease at higher concentrations of exogenous DNA (Fig. 3.3). A similar pattern of the number of transformants recovered was also seen in the yeast Saccharomyces cerevisiae, with the number of transformants recovered increasing up to a concentration of $1000 \mathrm{ng}$ DNA. At higher concentrations of added DNA, the number of transformed yeast cells decreased without obtaining a steady level (13). This type of curve appears to be fairly common among electroporated bacteria, with absolute values varying with the bacteria and vector used. It is apparent that exogenous DNA concentrations higher than $80 \mathrm{ng}$ are in some manner detrimental to the survival of the bartonellae (as well as the yeast). Unfortunately, this type of experiment was not performed with $R$. quintana and we have no other data of this type for relatives of $B$. bacilliformis. A study of the effect of DNA concentration on the percent of bacterial cell survival could be beneficial in understanding this decline in the number of stably transformed organisms.

The survival percentages obtained (Fig. 3.4) were also consistent with the data obtained for other microorganisms. Throughout the literature, optimal transformation efficiencies range from 20 to $50 \%$ cell survival $(15,41,14,13)$.

This optimized system allows the introduction of exogenous DNA into the previously untransformable B. bacilliformis at rates of survival and with transformation efficiencies similar to several other bacterial species including $R$. quintana and 
Pseudomonas aeruginosa (41, 14). A comparison of chromosomal digests of both transformed and untransformed bartonellae (Fig. 3.5), as well as comparison of SDS-PAGE cell lysate protein profiles (Fig. 3.6), suggest that $B$, bacilliformis is surviving the electroporation protocol and subsequently replicating. This study shows that $B$. bacilliformis is capable of utilizing the RK2 origin of replication, as well as having the ability to express the kanamycin resistance gene of pEST (Fig. 1.2).

The lack of success in the transformation of $B$. bacilliformis with the vectors pUCK18, pML31, and pMK20 (pMB1, F, and ColEl origins, repectively) was not surprising. None of these vectors had been used with success in the transformation of the closely-related bacterium, $R$. quintana (41). In addition, we restricted our vectors to those which contained only a kanamycin resistance gene, due to the inability to use kanamycin as a chemotherapeutic agent in clinical cases of oroya fever. Because of this restriction, we were unable to attempt transformation of B. bacilliformis with the vector psup204Ts (chloramphenicol resistance, replicons pMB1 and RSF1010 [39]), which had been the only other vector successful in the transformation of $R$. quintana (41). It is apparent that of the four replicons used, only the RK2 origin of replication is stably functional in $B$. bacilliformis.

Upon electroporation of the bartonellae with the additional vectors, there was apparent $B$. bacilliformis growth evident at approximately 8 days of incubation. We feel that this was due to 
unstable replication of the exogenous DNA and transient kanamycin resistance. The colonies observed were smaller than those seen with pEST-transformed bartonellae, and additional growth time was required to visualize the colonies. In addition, the number of colonies observed was very low as compared to that of the pESTtransformed bacteria. These observations can possibly be explained by the generation time of $B$. bacilliformis $(\sim 14 \mathrm{~h})$; unstable transformation would occur in a reduced number of bacteria, and it would subsequently take longer to visualize the colonies ( $\sim 8$ days instead of 6$)$. In addition, the 'transformants' would eventually lose their resistance to the kanamycin (i.e. no plasmid replication) resulting in smaller, as well as fewer, colonies formed.

The lack of transformation success using these vectors is beneficial in determining what requirements $B$. bacilliformis might have to accept and utilize exogenous DNA. We now know that several replicons do not function in bartonellae. We also know that $B$. bacilliformis is capable of utilizing a kanamycin resistance gene as demonstrated by both the successful transformation with PEST and the unstable transformation exhibited by bartonellae electroporated with the other three vectors.

Mutagenesis of $B$. bacilliformis with the Tn5-containing suicide vector pRKTV14 (Table 1.1, [52]) was also unsuccessful. This lack of success is most likely due to the colel replicon present on the vector. This replicon was present on the plasmid 
pMK20, and does not appear to be functional in bartonellae. As with the three unsuccessful vectors, bartonellae exhibited unstable transformation when electroporated with pRKTV14, suggesting that an unstable transformation event occured. To successfully mutagenize $B$. bacilliformis, a suicide vector should be constructed containing both an RK2 origin of replication as well as Tn5, which carries a kanamycin resistance marker. A search of the literature indicates that there are several vectors which could be manipulated to fullfill these requirements. Once constructed, a vector compatible with $B$. bacilliformis could be introduced into bartonellae with relative ease using the system of electroporation which we have specifically optimized for this bacterium. 


\section{BIBLIOGRAPHY}

1. Arias-stella, J., P. Lieberman, R. Erlanson, and J. Ariasstella, Jr. 1986. Histology, immunohistochemistry, and ultrastructure of the verruga peruana in Carrion's disease. Am. J. Surg. Pathol. 10:595-610.

2. Ausubel, F.M., R. Brent, R.E. Kingston, P.D. Moore, J.G. seidman, J.A. Smith, and K. struhl. 1989. Short Protocols in Molecular Biology. Harvard Medical School. Wiley and Sons, New York.

3. Benson, L.A., S. Kar, G. McLaughlin, and G.M. Ihler. 1986. Entry of Bartonella bacilliformis into erythrocytes. Infect. Immun. 54:347-353

4. Birnboim, H.C., and J. Doly. 1979. A rapid alkaline extraction for screening recombinant plasmid DNA. Nucleic Acids Res. 7:1513-1523.

5. Brenner, D., S. O'Connor, D. Hollis, R. Weaver, and A. steigerwalt. 1991. Molecular characterization and proposal of a neotype strain for Bartonella bacilliformis. J. Clin. Microbiol. 29:1299-1302.

6. Cohen, S., A. Chang, and I. Hsu. 1972. Nonchromosomal antibiotic resistance in bacteria: genetic transformation of Escherichia coli by R-factor DNA. Proc. Natl. Acad. Sci. USA. $69: 2110-2114$.

7. Chu, G., H. Hayakawa, and P. Berg. 1987. Electroporation for the efficient transfection of mammalian cells with DNA. Nucleic Acids Res. 15:1311-1326. 
8. Chung, C.T., S.I. Niemela, and R.H. Miller. 1989. One step preparation of competent Escherichia coli: transformation and storage of bacterial cells in the same solution. Proc. Natl. Acad. Sci. USA. 86:2172-2175.

9. Cuadra, C.M. 1956. Salmonellosis complication in human bartonellosis. Tex. Rep. Biol. Med. 14:97-113.

10. Cuadra, M., and J. Takano. 1969. The relationship of Bartonella bacilliformis to the red blood cell as revealed by electron microscopy. Blood. 33:708-716.

11. Dagart, M., and S.D. Ehrlich. 1979. Prolonged incubation in calcium chloride improves the competence of Escherichia coli cells. Gene. 6:23-28.

12. Davis, R.W., D. Bostein, and J.R. Roth. 1980. Advanced Bacterial Genetics. Cold Spring Harbor Laboratory, cold Spring Harbor, N.Y.

13. Delorme, E. 1989. Transformation of Saccharomyces cerevisiae by electroporation. Appl. Environ. Microbiol . 55:2242-2246.

14. Diver, J.. I. Bryan, and P. sokol. 1990. Transformation of Pseudomonas aeruginosa by electroporation. Anal. Biochem. $189: 75-79$

15. Dower, w., J. Miller, and C. Ragsdale. 1988. High Efficiency transformation of Escherichia coli by high voltage electroporation. Nuc. Acid Res. 16:6127-6145

16. Feinberg, A.P. and B. Vogelstein. 1984. Addendum: a technique for radiolabelling DNA restriction endonuclease fragments to high specific activity. Anal. Biochem. 
$137: 266-267$

17. Fromm, M., L. Taylor, and V. Nalbot. 1985. Expression of genes transferred into monocot and dicot plant cells by electroporation. Proc. Natl. Acad. Sci. USA. 82:5824-5828.

18. Garcia, F.U., J. Wojta, K.N. Broady, J.M. Davidson, and R.I. Hoover. 1990. Bartonella bacilliformis stimulates endothelial cells in vitro and is angiogenic in vivo. Am. J. Pathol. 136:1125-1135.

19. Garcia-caceres, U. and F.U. Garcia. 1991. Bartonellosis: an immunodepressive disease and the life of Daniel Alcides Carrion. Amer. J. Clin. Pathol. 95:558-566.

20. Glenn, A., F. Roberto, and T. Nard. 1992. Transformation of Acidiphilium by electroporation and conjugation. Can. J. Microbiol. 38:387-393.

21. Hanahan, D. 1983. Studies on transformation of Escherichia coli with plasmids. J. Mol. Biol. 166:557-580.

22. Hartshone, R., B. Reller. J. Talvenheimo, W. Catteral, and M. Montal. 1985. Functional reconstitution of the purified brain sodium channel in planar lipid bilayers. Proc. Natl. Acad. Sci. USA. 82:240-244.

23. Herrer, A. 1953. Carrion's disease. II. Presence of Bartonella bacilliformis in the peripheral blood of patients with the benign form. Am. J. Trop. Med. 2:645-649.

24. Hertig, M. 1942. Phlebotomus and Carrion's disease. Am. J. Trop. Med. 22:1-76.

25. Hill, E. McGinnis, A. Raji, M. Valenzuela, F. Garcia, and R. 
Hoover. 1992. Adhesion to and invasion of cultured human cells by Bartonella bacilliformis. Infect, and Immun. $60: 4051-4058$

26. Hurtado, A., J.P. Musso, and E. Merino. 1938. La anemia en la enfermadad de Carrion (verruga peruana). Ann. Fac. Med Lima. $28: 154-168$.

27. Joklik, W., H. Willett, D.B. Amos, and c. Nilfert. 1992. Rickettsiae, p.700-718. In: Zinsser microbiology, 20th ed. Appleton and Lange, San Mateo, Calif.

28. Kahn, M., R. Kolter, C. Thomas. D. Figurski, R. Meyer, E. Remaut, and D.R. Helinski. 1979. Plasmid cloning vehicles derived from plasmids ColE1, F, R6K, and RK2. Methods Enzymol. $68: 268-280$.

29. Knobloch, J., I. Solano, O. Alvarez, and E. Delgado. 1985. Antibodies to Bartonella bacilliformis as determined by flourescence antibody test, indirect hemagglutination, and ELISA. Trop. Med. Parasitol. 36:183-185.

30. Rreier, J.P. and M. Ristic. 1981. The biology of hemotrophic bacteria. Annu. Rev. Microbiol. 35:325-338.

31. Laemmii, u.K. 1970. Cleavage of structural proteins during the assembly of the head of bacteriophage T4. Nature (London) . $227: 680-685$.

32. Lovett, M.A., and D.R. Helinski. 1976. Method for the isolation of the replication region of a bacterial replicon: construction of a mini-F' $k m$ plasmid. J. Bacteriol. 127:982-987. 
33. Mandel, M., and A. Higa. 1970. Calcium-dependent bacteriophage DNA infection. J. Mol. Biol. 53:159-162.

34. Mernaugh, G., and G. Inler. 1992. Deformation factor: an extracellular protein synthesized by Bartonella bacilliformis that deforms erythrocyte membranes. Infect. Immun. $60: 937-943$.

35. Miller, J. W. Dower, and I. Tompkins. 1988. High-voltage electroporation of bacteria: genetic transformation of Campylobacter jejuni with plasmid DNA. Proc. Natl. Acad. SCi. USA. $85: 856-860$

36. Minnick, M.F., and G.L. Stiegler. 1993. Nucleotide sequence and comparison of the $5 \mathrm{~S}$ ribosomal RNA genes of Rochalimaea henselae, $R$. quintana, and Brucella abortus. Nucleic Acids Res. 21:2518.

37. Norgard, M., K. Kleem, and J. Monahan. 1978. Factors affecting the transformation of Escherichia coli strain chi1776 by pBR322 plasmid DNA. Gene 3:279-292.

38. O'Connor, S.P., M. Dorsch, A.G. Steigerwalt, D.J. Brenner, and E. Stackebrandt. 1991. 16S rRNA sequence of Bartonella bacilliformis and cat scratch disease bacillus reveal phylogenetic relationships with the alpha-2 subgroup of the class Proteobacteria. 1991. J. Clin. Microbiol. $29: 2144-2150$.

39. Potter, H., L. Weir, and P. Leder. 1984. Enhancer-dependent expression of human $\mathrm{k}$ immunoglobulin genes introduced into mouse pre-B lymphocytes by electroporation. Proc. Natl. 
Acad. Sci. USA. 81:7161-7165.

40. Relman, D., P. Lepp, K. sadler, and T. Schmidt. 1992 . Phylogenetic relationships among the agent of bacillary angiomatosis, Bartonella bacilliformis, and other alphaproteobacteria. Mol. Microbiol. 6:1801-1807.

41. Reschke, D.K., M.E. Frazier, and L. P. Mallavia. 1990. Transformation of Rochalimaea quintana, a member of the family Rickettsiaceae. J. Bacteriol. 172:5130-5134.

42. Ristic, M., and J.P. Rreier. 1984. Family II. Bartonellaceae Giesczykiewicz 1939, p.717-719. In: N. R. Krieg and J. G. Holt (ed.), Bergey's Manual of systematic Bacteriology. Williams and Wilkins Co., Baltimore, MD. 1:717-719.

43. Sambrook, J., E.F. Fritsch, and T. Maniatis. 1989. Molecular cloning: a laboratory manual, 2nd ed. Cold spring Harbor Laboratory, cold spring Harbor, N.Y.

44. Schultz, M. 1968. A history of bartonellosis (Carrions disease). Ar. J. Trop. Med. 17:503-515.

45. Southern, E.M. 1975. Detection of specific sequences among DNA fragments separated by gel electrophoresis. $\mathbf{J}$. Mol. Biol. 98:503-517.

46. Tsien, R., P. Hess, E. Mcclesky, and R. Rosenberg. 1987. Calcium channels: mechanisms of selectivity, permeation, and block. Annu. Rev. Biophys. Biophys. Chem. 16:265-290.

47. Tsong, T. 1991. Electroporation of cell membranes. Biophys. J. $60: 297-305$.

48. Watson, J., H. Hopkins, J. Roberts, J. Argetsinger steitz, 
and A. Weiner. 1987. The genetic systems provided by Escherichia coli and it's viruses, p. 177-213. In: Molecular biology of the gene, Vol. 1, 4th ed. The Benjamin/Cummings Publishing Company, Inc., Menlo Park, Calif.

49. Wray, W., T. Boulikas, V.P. Wray, and R.H. Hancock. 1981. Silver staining of proteins in polyacrylamide gels. Anal. Biochem. $118: 197-203$.

50. Veinman, D. 1965. The Bartonella group, p. 775-785. In: R. J. Dubos and J.G. Hirsch (ed.) Bacterial and mycotic infections of man. J. B. Lippincott Co., Philadelphia.

51. Zimmermann, U., and J. Vienken. 1982. Electric field-induced cell-to-cell fusion. J. Membr. Biol. 67:165-182.

52. Zylstra, G., W. R. Mccombie, D. Gibson, and B. Finette. 1988. Toluene degradation by Pseudomonas putida F1: genetic organization of the tod operon. Appl. Environ. Microbiol. $54: 1498-1503$ 